Ann. Génét. Sél. anim., I977, 9 (4), 459·452.

\title{
Cytogenetic analysis of cattle chromosomes; current utilization and speculation of future applications ${ }^{(1)}$
}

\author{
I. GUSTAVSSON
}

\author{
Department of Animal Breeding and Genetics, \\ The Swedish University of A gricultural Sciences, \\ S-750 o7 Uppsala 7, Sweden
}

\section{Summary}

The development over the last 20 years of a cytogenetic branch in cattle genetics has been considered. The various chromosomal anomalies encountered in cattle are subdivided in 3 groups according to phenotypic manifestations:

- chromosomal anomalies with grave effects on conformation and/or fertility;

- chromosomal polymorphism with small phenotypic effects;

- secondary anomalies which presumably are parts of the phenotype.

It is concluded that chromosomal abnormalities with grave effects on conformation and fertility are rapidly eliminated by artificial selection and mean no great economic losses for agriculture. Nevertheless the cytogenetical investigations of those anomalies are of importance for a correct diagnosis of the phenotypic condition concerned. On the contrary chromosomal polymorphisms, due to their small phenotypic effects, mean great risks for distribution of chromosomal aberrations in the population. Too little is still known about aberrations such as chromosome breaks and small deletions but most often they appear to be parts of the phenotypic effects.

Different trends of developing cattle cytogenetics are considered and future applications of cytogenetics to chromosome mapping, genetic engineering and embryo transfer are briefly discussed. The development and application of banding techniques will, no doubt, reveal in the near future a host of hitherto undescribed chromosome markers. It is stressed that new ideas must be introduced to get cytogenetics further established as an important research branch of practical cattle breeding.

When we start the present section containing many, what I hope, very interesting communications in cattle cytogenetics it is quite natural to ask: What is the current use of cattle cytogenetics and What will future purposes of the discipline be? Particularly the last question I have asked myself several times. Of course I am not the right person to answer, but I can at least briefly draw the principal lines of cattle cytogenetics, give some personal thoughts on the future and in that way hope to provoke you to discussions. I suppose our following communications of to-day and to-morrow will deal with the details of each special field of cattle cytogenetics.

The first observations of cattle chromosomes were carried out 50 years ago (KRALIINGER, I927), but chromosome pictures as we are used to see them occurred much later. I would like to remind you that it was just twenty years ago that the first cattle chromosomes from tissue-cultured cells were obtained (MELANDER,

(I) This article has been presented to the 3 rd Colloquium on cytogenetics of domestic animals, may 31 june 2 1977, Jouy-en-Josas, France. 
I957). We had to wait until the next decennium, however, to know more about chromosomes of cattle, but, during the late sixties and early seventies a number of phenotypic malformations were associated with chromosome aberrations (for a review see RIECK, I974). At the turn of I969-I970 the first new staining techniques were introduced which for cattle cytogenetics culminated in 1976 with the description in Reading, England, of an international standard arrangement of the chromosomes into a karyotype (Proceedings of the First International Conference for the Standardisation of Banded Karyotypes of Domestic Animals, to be published).

If we consider the work done during the last 20 years we might divide the chromosome aberrations into three groups according to phenotypic manifestations which are given within parenthesis.

I. Chromosomal anomalies: Autosomal trisomy (Brachygnatia inferior), $\mathrm{XX} / \mathrm{XY}$ chimerism (freemartinism), autonomous $\mathrm{XX} / \mathrm{XY}$ (intersexuality), XXY (hypogonadism), tandem fusion (reduced fertility), etc.

2. Chromosomal polymorphisms: I/29 and other centric fusion translocations (reduced fertility).

3. Secondary chromosome anomalies: Chromosome breaks and deletions (gonadal hypoplasia, subfertility, etc.).

The first group, here labelled chromosomal anomalies, include spontaneous or familiarly occurring cases of cattle more or less malformed and /or with greatly reduced fertility. Common for this group of animals is that they mean little risks for extensive distribution of the anomaly concerned. Summarizing the information hitherto available we must concede that very few chromosomal anomalies (with the exception of XX/XY chimerism) have been associated with considerable phenotypic abnormalities in cattle, and for each type of anomaly only a few cases have been described. Then the question arises: Why are the incidences so low compared to corresponding incidences in man? Even though we don't know if mutation rates are similar in the two species one reasonable explanation would be that the phenotypic abnormalities in cattle seldom come to investigation. Anyway I think the conclusion is correct if I say that chrosomome anomalies giving considerable phenotypic effects don't represent important economical losses for agriculture because such anomalies become eliminatcd very quickly from the cattle population due to their pathological effects. Nevertheless and it should be stressed very hard the knowledge and the study of the cytogenetical background is often of utmost importance for the outcome of a correct diagnosis and is also of great importance for the understanding of similar conditions in man.

The second group of chromosome deviations, chromosomal polymorphisms, presents a quite different problem. Evidently those types of aberrations constituting polymorphic systems give very small phenotypic manifestations such as a small reduction of fertility. The last fact concerns at least th $2 \mathrm{I} / 29$ translocation (Gustavsson, I969; REFSDAL, I976) and I am bold enough to say that we had better presume the same also for other centric fusion translocations occurring in A. I. populations. The small deviations in phenotypic effects mean that there are great risks for extensive distribution of such polymorphic systems and in cattle populations making use of A. I. it is therefore absolutely necessary to keep the cytogenetic situation under control with continuous investigations of breeding animals. Although direct cytogenetical proofs of reduced fertility are still lacking, I think the fertility figures for the I/29 translocation are so convincing that we should discuss if it is not highly urgent to introduce recommendations about cyto- 
genetic investigation before transfer of breeding materials between countries.

There is also a third group of chromosome aberrations, here labelled secondary chromosome anomalies. We know very little of those types of ancmalies but the chromosome anomaly appears to be a part of the phenotypic effects.

Due to the need of diagnosis and the control of cattle intended for breeding work to-day's cattle cytogenetics has been founded on the first two groups of chromosome aberrations. Those reasons have been and still are good motives for the establishment of cytogenetic laboratories in different parts of the world.

What will be the future of cattle cytogenetics? Of course we have to expect that further work involving application of new techniques will increase our knowledge of different chromosome aberrations and their phenotypical manifestations. Since there are still large cattle populations hitherto quite unknown from the chromosomal point of view it may be possible to find new polymorphic systems which are geographically widespread. With the increasing utilization of A.I., routine cytogenetic investigations will get increased importance. Therefore I think the initiative, at present meeting, of Paul Popescu to continue the work, started by David Pollock, in Reading I976, compiling present knowledge about number of cattle analysed in each breed, breed incidences and types of aberrations is worth encouragement. As Mike Harvey expressed some years ago (HARVEY, I974) it is urgent to form an international central reference library where the results of all chromosomal analyses carried out could be deposited and published.

However, when we are talking of future trends in cattle cytogenetics we must not only look to the near future but be as far-seeing as possible. In a strained financial world it is necessary, as you know, to have a long term plan for your projects. At least in my country we are to-day confronted with the problem that developing cytogenetics must include projects in which the outcome means predictable return of money. Although our works have given what we think important results for diagnosing different abnormal conditions and increasing fertility of cattle in Sweden, cytogenetics is still considered by many people to be, a very exclusive science of genetics, of small economical importance, and with little possibilities of development. I suppose several collegues here also have met the same experience and I am quite sure that everyone who wants to increase his resources will be confronted with the arguments I just mentioned.

It is of course not easy to predict future development of cattle cytogenetics, but I think it is evident that we must present new ideas on how to use cytogenetics in future animal breeding. It is to-day not easy to predict future use of chromosome maps, genetic engineering techniques and so on, but personally I am quite sure that manipulations of the hereditary material will gain increased interest in the near future because of the rapid development of egg transplantation techniques. I would also like to point out the practical utilization of so-called chromosome markers wbich I think will be very important in research as well as in routine work. The sex chromosomes have been important chromosome markers since they indicate the sex of the animal. The type of work carried out by Doug Hare and coworkers (HARE et al., I976) by sexing embryos before cryopreservation and/or transplantation will be one very important task for future cytogenetics. The new banding techniques have given us very detailed information of individual chromosomes and it is my and my co-workers impression that there is a very extensive variability in chromosome banding patterns within several domestic animals. Some years ago Paul PoPESCU (I974) demonstrated centromere polymorphism in the cattle chromosomes by using C-banding, and we have observed the same phenomenon using the $\mathrm{T}$ technique. Extensive chromosome variability, similar 
to that observed between different inbred strains of the laboratory mouse (MrLLER et al., I976), thus make possible identification of the single individuals. Such a system can be used for several in vivo as well as in vitro experiments.

Finishing my brief introduction it is my hope that the present meeting will give some new ideas and also provoke the participants to take up discussions of future developments.

$$
\text { Rę̧u pour publication en décembre } 1977 .
$$

\section{Résumé \\ Analyse cytogénétique des chromosomes de Bos taurus L. : utilisation courante et applications futures}

On a envisagé le développement de la cytogénétique des bovins au cours des 20 dernières années. Les différentes anomalies chromosomiques rencontrées ont été divisées en trois groupes selon leurs manifestations phénotypiques :

- anomalies chromosomiques avec effets graves sur la conformation et ou la fertilité;

- polymorphismes chromosomiques avec de légers effets phénotypiques;

- anomalies secondaires qui probablement font partie du syndrome.

On conclut en disant que les anomalies chromosomiques accompagnées d'effets graves sur la conformation et la fertilité sont rapidement éliminées par la sélection et ne causent pas de pertes économiques importantes à l'agriculture. Néanmoins, les investigations cytogénétiques de ces anomalies ont une certaine importance pour un diagnostic correct de l'anomalie en question. Au contraire les polymorphismes chromosomiques à cause de leurs légers effets pléiotropiques présentent un grand risque de dispersion des anomalies chromosomiques dans la population. Trop peu de chose est encore connu sur les aberrations telles que les cassures chromosomiques et les petites délétions mais la plupart du temps elles semblent être des éléments du tableau phénotypique.

Les différentes tendances qui se manifestent au sein de la cytogénétique des Bovins ont été dégagées et on a discuté des futures applications de la cytogénétique à la carte chromosomique, à l'ingénierie génétique et au transfert des embryons. Les développements des techniques des bandes et leurs applications révèleront certainement une légion de marqueurs chromosomiques non encore décrits. On a insisté sur le fait qu'il faut faire un effort d'imagination pour que la cytogénétique devienne une activité de recherche active pour épauler la pratique de l'élevage.

\section{Références}

Gustavsson, I., I969. Cytogenetics, distribution and phenotypic effects of a translocation in Swedish cattle. Hereditas, 63, 68-169.

Hare W. C. D., Mitchely D., Betteridge K. J., Eaglesome M. D. and Randai.L G. C. B., i 976. Sexing two week old bovine embryos by chromosomal analysis prior to surgical transfer: preliminary methods and results. Theriogenology, 5, 243-253.

Harvey, M. J. A., I974. Cytogenetic studies in bulls. Vet. Rec., 95, 353.

KRALIINGER H. F., 1927. Uber die Chromosomenzahl beim Rind sowie einige allgemeine Bemerkungen über die Chromosomenforschung in der Säugeierklasse. Anat. Anz., 63, 209-2I4 (Erg.-Heft).

MELANDER Y., I957. On the chromosome complement of some domestic animals. In T. Caspersson Report From the First Swedish Conference of Cell Research, I957. Arch. Zool. (Stockholm), Ser. 2, 11, r22.

Mililer D. A., Tantravahi R., Dev V. G. and Millek O. J., r976. Q- and C-band chromosome markers in inbred strains of Mus musculus. Genetics, 84, 67-75.

POPESCU C. P., I974. Étude du caryotype bovin par une nouvelle méthode cytogénétique: les bandes C. Ist World Congress on Genetics Applied to Livestock Production, Symposia 3, Madrid 7-I I October, I974, pp. I 59-I68.

REFSDAL, A. O., I976. Low fertility in daughters of bulls with $1 / 29$ translocation. Acta vet. scand., 17, I90-195.

RIECK G. W., I974. Chromosomenanomalien und ihre pathologischen Folgeerscheinungen bei der Haustieven. - Ist World Congress on Genetics Applied to Livestock Production. I. Plenary sessions, Madrid 7-I I October, I974, pp. I I7-I9o. 